IZA DP No. 7389

Negative and Positive Assimilation

By Prices and By Quantities

Barry R. Chiswick

Paul W. Miller

May 2013 


\title{
Negative and Positive Assimilation By Prices and By Quantities
}

\author{
Barry R. Chiswick \\ George Washington University \\ and IZA \\ Paul W. Miller \\ Curtin University \\ and IZA
}

Discussion Paper No. 7389

May 2013

IZA

P.O. Box 7240

53072 Bonn

Germany

Phone: +49-228-3894-0

Fax: +49-228-3894-180

E-mail: iza@iza.org

\begin{abstract}
Any opinions expressed here are those of the author(s) and not those of IZA. Research published in this series may include views on policy, but the institute itself takes no institutional policy positions. The IZA research network is committed to the IZA Guiding Principles of Research Integrity.

The Institute for the Study of Labor (IZA) in Bonn is a local and virtual international research center and a place of communication between science, politics and business. IZA is an independent nonprofit organization supported by Deutsche Post Foundation. The center is associated with the University of Bonn and offers a stimulating research environment through its international network, workshops and conferences, data service, project support, research visits and doctoral program. IZA engages in (i) original and internationally competitive research in all fields of labor economics, (ii) development of policy concepts, and (iii) dissemination of research results and concepts to the interested public.
\end{abstract}

IZA Discussion Papers often represent preliminary work and are circulated to encourage discussion. Citation of such a paper should account for its provisional character. A revised version may be available directly from the author. 


\section{ABSTRACT}

\section{Negative and Positive Assimilation By Prices and By Quantities*}

This paper considers the labor market assimilation of immigrants in terms of earnings and employment (employment probability, unemployment probability, and hours worked per week). Using the 2006 Australian Census of Population and Housing the analyses are performed separately by gender, and separately by whether or not the origin is an Englishspeaking developed country (ESDC). Among men in general, 'negative assimilation' is found for immigrants from the ESDC, and positive assimilation for other origins. Among women, the pattern of assimilation in earnings and employment is more positive than among their male counterparts. This may reflect the greater tendency for female immigrants to be tied movers. Among never married immigrant women from the ESDC, who are more likely than married immigrant women from the same countries to be economic migrants, the pattern of negative assimilation is observed.

JEL Classification: J61, J31, F22

Keywords: immigrants, assimilation, earnings, hours worked, employment, unemployment

Corresponding author:

Barry R. Chiswick

Department of Economics

George Washington University

2115 G Street, NW

Monroe Hall 340

Washington, DC 20052

USA

E-mail: brchis@uic.edu

\footnotetext{
* Miller acknowledges financial assistance from the Australian Research Council. We are grateful to Derby Voon and Marina Gindelsky for research assistance.
} 


\section{NEGATIVE AND POSITIVE ASSIMILATION BY PRICES AND BY QUANTITIES}

\section{INTRODUCTION}

Research into the economic adjustment of immigrants has largely had a focus on the changes in their earnings with duration of residence in the destination country (Chiswick, 1978). The typical adjustment profile established in this literature is one of initial earnings disadvantage, followed by a period of relatively rapid increases in earnings, with the rate of increase decreasing over time. This is the stereotype pattern of positive wage assimilation.

Chiswick (1982), Antecol, Kuhn and Trejo (2006) and Miller and Neo (2003) have widened the scope of the labor market outcomes considered in this positive assimilation literature through examination of labor force status: the employment probability in the case of Antecol et al. (2006), the probability of unemployment in the case of Miller and Neo (2003), and employment, unemployment and weeks worked in Chiswick (1982). Antecol et al.'s (2006) study concluded that there was strong evidence of positive employment assimilation among male immigrants. Miller and Neo (2003) reported that male immigrants in Australia experienced relatively high rates of unemployment in the immediate post-arrival period, but this disadvantage dissipated with length of residence. This study also, therefore, finds evidence of positive employment assimilation. Chiswick (1982) found that while recently arrived immigrants worked for fewer weeks than the native born, the weeks worked among established immigrants were generally comparable to those of their native-born counterparts.

Chiswick and Miller (2011)(2012) have recently argued that earnings assimilation patterns should differ between immigrants moving among countries where the skills are highly transferable, such as among the English-speaking developed countries, and those who move 
between countries where the skills are not highly transferable. They advanced a model where the former group of immigrants would be characterized by 'negative' wage assimilation, in contrast to the 'positive' wage assimilation of the latter group of immigrants. ${ }^{1}$ This model was tested using earnings data for male immigrants to the United States and Australia from the major English-speaking immigrant-origin countries. Empirical support for the negative wage assimilation hypothesis was reported. ${ }^{2}$ Related to this research, Blau, Kahn and Papps (2011) examine labor market assimilation among immigrants in the United States, using annual hours worked as the index of assimilation. They find that there is positive assimilation for most groups of immigrants, though notable exceptions were immigrants from English-speaking countries and immigrants from countries where English was an official language. This evidence is consistent with the negative assimilation hypothesis (Chiswick and Miller, 2011).

The objective of this paper is to expand the study of Chiswick and Miller (2011) through examination of the patterns of employment, unemployment, hours worked and earnings assimilation for both males and females. The analyses are undertaken for the Australian labor market, a labor market argued by Miller and Neo (2003) and Cobb-Clark and Crossley (2004) to be characterized by considerable wage rigidities that enhanced the prospect of immigrant adjustment occurring through employment rather than earnings. As such it provides a strong

\footnotetext{
1 'Positive Assimilation' refers to the rise in earnings with duration in the destination due to the acquisition of skills and labor market information and networks relevant to the destination. 'Negative Assimilation' refers to the decline in earnings with duration in the destination due to the decline in the economic rent that prompted the migration.

${ }^{2}$ In addition to this evidence for immigrants among English-speaking countries, the study by Pedersen et al. (2008, pp.105-6, Table 5.8), of immigrants in Sweden, was also consistent with the negative wage assimilation hypothesis for Nordic immigrants and positive assimilation for immigrants from Central and Eastern Europe.
} 
testing ground for the negative (employment) assimilation hypothesis. The analyses are based on the 2006 Australian Census of Population and Housing.

The structure of the study is as follows. Section II provides a brief overview of the two models of immigrant economic adjustment: the positive assimilation model and the negative assimilation model. Section III describes the data. Section IV examines the patterns of wage adjustment for immigrants to Australia from the English-speaking developed countries, and contrasts these with the patterns for immigrants from the other countries. Section V examines the pattern of change in the probabilities of employment and unemployment for these two groups of immigrants, as well as changes in the hours worked of the employed. A set of sensitivity analyses are presented in Section VI, while Section VII concludes.

\section{MODELS OF IMMIGRANT ECONOMIC ASSIMILATION}

The positive immigrant assimilation model of Chiswick (1978), in its simplest form, has three components. First, due to differences across countries in level of economic development, institutions and labor markets, the skills immigrants accumulate in their country of origin are not fully transferable to the destination country. These skills include formal schooling, on-the-job training, language skills, and general knowledge of the functioning of labor markets. Second, due to this less-than-perfect international transferability of human capital skills, and immigrants' response to this through investment in skills relevant for the destination, immigrants will experience considerable wage disadvantages compared to their native-born counterparts immediately after arrival. Third, as investment activity becomes less intense, and as the returns on the post-arrival investments accrue, immigrants' earnings increase, initially quite rapidly, with length of residence in the country of destination, then more slowly. This post-arrival increase in 
wages is what is now commonly referred to as positive assimilation. Much of the empirical research in the economics of immigration field has been devoted to quantifying aspects of this positive assimilation process.

In contrast, Chiswick and Miller (2011) consider migration between countries with similar labor markets, institutions, languages, and stages of economic development. It is argued that immigration in such situations where skills are highly, if not almost perfectly, transferable is likely to be in response to a favorable draw from the wage distribution in the destination country. An immigrant attracted to Australia to work in the high-wage mining sector at the current time would be an example. Consequently, in the immediate post-arrival period, immigrants would typically initially have higher earnings than their native-born counterparts, because that is what induced the move. The question then is what the future time path of the immigrant's wage will look like? Will they continue to earn relatively high wages, given their human capital skills, or will their position in the wage distribution be subject to a regression to the norm for their skills? Chiswick and Miller (2011) argue that the favorable economic circumstances in sectors of the economy tend not to persist over extended periods of time, and hence a regression to the norm for the immigrant's skills is likely.

Even if such favorable economic conditions in a particular sector could be sustained, if the initial wage offer exceeded the immigrant's true value of marginal product, perhaps because of a high wage draw for random reasons, subsequent wage offers should be more aligned with the immigrant's productivity, in the spirit of the signalling literature. This 'regression to the norm for their skills' in the immigrant's wage, or the decline in the economic rent that stimulated the move, would be expected to occur in terms of real wages, if not in nominal wages. This pattern, 
whereby the ceteris paribus wage declines with duration of residence, is what was termed negative assimilation in earnings by Chiswick and Miller (2011).

The negative wage assimilation model of Chiswick and Miller (2011) is based on the incentives for primary movers who are purely economic migrants. The effects under this model would be much weaker, or non-existent, for migrants among the English-speaking developed countries (ESDC) if they are non-economic migrants. Included in this category would be tied movers, refugees, and ideological migrants, though the main group of non-economic migrants among ESDC immigrants in the US or Australia would be tied movers. The best approximation to tied movers is married women, although it needs to be acknowledged that not all married women are tied movers. Accordingly, the analyses below will investigate whether the negative assimilation hypothesis applies to female immigrants as well as male immigrants, and among women does it apply equally to tied movers and economic migrants.

The analyses presented in this paper also examine whether negative assimilation is a characteristic of the probability of employment and the incidence of unemployment, as well as weekly hours worked. The expected patterns of labor quantity adjustment with duration of residence in the destination country have not been explicit in the conceptual frameworks of Chiswick (1978) and Chiswick and Miller (2011). As is apparent from the discussion in Chiswick (1982), Antecol et al. (2006) and Miller and Neo (2003), the economic reasoning behind immigrants' positive wage adjustment carries over to the changes in the probabilities of employment and unemployment with duration of residence. In other words, it would be expected that in the immediate post-arrival period, due to the less-than-perfect international transferability of human capital skills, immigrants from non-English-speaking countries will have relatively low (high) probabilities of employment (unemployment) in an English-speaking developed 
destination, and that this disadvantage will dissipate with years of residence in the host country. Immigrants from developed English-speaking countries are argued in Chiswick and Miller's (2011) negative assimilation model to be motivated to migrate by a relatively favorable job offer. This implies relatively high (low) probabilities of employment (unemployment) in the immediate post-arrival period. Similar to the wage dynamics, the employment and unemployment experiences of immigrants from developed English-speaking countries are expected to regress to the norm for their set of skills with length of stay in the destination. Trajectories with duration of residence similar to those for the employment probability would be expected in the case of hours worked per week.

The labor market experiences of female immigrants have not been studied to the same extent as those of males, due to the greater selectivity in participating in the paid labor force, and the practical difficulties of accommodating this sample selection in empirical work. Cobb-Clark (1993) is a notable exception. Many female immigrants are likely to experience what Beach and Worswick (1993) have described as a double-disadvantage: they incur a labor market disadvantage because they are immigrants and a further disadvantage because they are female. Then, in the immediate post-arrival period, female immigrants are likely to experience relatively low earnings, employment probabilities (and high unemployment rates), and weekly hours worked. However, with increases in their length of stay in the destination country, they would be expected to experience improvement in their relative economic standing. Moreover, as the typical pattern of economic adjustment reported in the literature is that the speed of this positive adjustment is inversely related to the extent of the initial disadvantage, it is expected that the 
improvements in the wage, employment, weekly hours worked, and unemployment positions of female immigrants with duration of residence will be much stronger than those of males. ${ }^{3}$

The general patterns described above for females are likely to match the experiences of immigrants from countries with labor markets, institutions, languages and cultures that differ from those of the host country. In the case of immigrants from countries with highly transferable skills, it would be expected that the immediate post-arrival experience would be more favorable, though as many are likely to be tied movers, the ceteris paribus wage advantage that characterizes their male (primary mover) counterparts is less likely. Instead, the post-arrival experience is likely to be a weakened version of that which characterizes immigrants from nonEnglish-speaking countries. Marital status among female immigrants is used as a proxy for whether they are economic migrants (primary movers) or tied movers.

\section{DATA}

The data for this study are drawn from the 2006 Australian Census of Population and Housing. This census was conducted on 8 August 2006, and a 5 percent random sample of records has been made available in the form of a confidentialised unit record file called the '2006 Census Sample File'. This file contains information on labor force status, sector of employment ${ }^{4}$,

\footnotetext{
${ }^{3}$ The family investment model could be used to argue that the female employment rate in the immediate post-arrival period will be relatively high, and hence the post-arrival improvements will be less than otherwise expected. The evidence on this model is, however, mixed: see Baker and Benjamin (1997), Blau, Kahn and Portela-Souza (2003) and Cobb-Clark and Crossley (2004).

${ }^{4}$ Under the Public Service Act 1999, there is the expectation that Australian Public Service workers will be Australian citizens. The citizenship condition can, however, be waived where it is appropriate to do so, such as in cases of a shortage of relevant skills. Appendix A shows that around 11 percent of male immigrants are in government jobs, as are 15-18 percent of female 
earnings, birthplace, and year of entry into Australia, together with the standard demographic variables that are generally used in studies of labor market outcomes. The birthplace data permit the identification of immigrants from the main English-speaking countries.

The year-of-arrival data for immigrants are presented in categorical form, with the data from 1956 to 2006 divided into 5-year arrival cohorts, and the pre-1956 group aggregated into one category. This latter category is, given the time that has elapsed since they came to Australia, of limited importance in studies of labor market activity, where the focus is generally restricted to individuals aged 20-64 years. In the most flexible specification used in the analyses, dichotomous variables for the year-of-arrival cohorts are used in the estimating equation. In other specifications, a continuous 'years of residence in Australia' variable has been formed using the mid-points of the year-of-arrival cohorts, and a value of 56 years for the open-ended, earlier arrivals category. The year of arrival information is also used in combination with the data on chronological age to limit the analyses to those who immigrated as adults (defined as arrival in Australia at or above the 2006 minimum school leaving age of 16 years ${ }^{5}$ ).

Most immigrants who arrive as children can be expected to have completed their schooling in Australia, and have superior English language skills, and so their labor market outcomes, and the way these change with duration of residence, may differ from those of the adult immigrants whose economic performance and adjustment is described under the positive assimilation and negative assimilation models. Because of the availability of the year of arrival

immigrants. Approximately 15 percent of Australian-born male workers and 20 percent of Australian-born female workers hold government sector jobs.

${ }^{5}$ For earlier arrival cohorts, a younger (15 years) compulsory school leaving age would apply, though this is not used is the analysis. 
data only in categories, however, this delineation of the sample will only be approximate. We examine whether the findings are sensitive to this measurement issue in Section VI.

Of greater importance to the study of the determinants of earnings is the presentation of the weekly income data in bands. Ten bands are used: (i) \$1-\$149; (ii) \$150-\$249; (iii) \$250\$399; (iv) \$400-\$599; (v) \$600-\$799; (vi) \$800-\$999; (vii) \$1000-\$1299; (viii) \$1300-\$1599; (ix) \$1600-\$1900; and (x) \$2000 or more. A continuous weekly income figure was computed from these data by using the mid-points of the bands, and a figure of $\$ 3,000$ for the open-ended upper category. Some previous studies have attempted to accommodate the categorical nature of the income data in the Australian Census by focussing on the weekly income data, analysing these using a grouped regression model, and using supply-side variables as regressors. ${ }^{6}$ In the current study, however, the census measure of weekly income was converted to a reasonably continuous hourly measure by dividing through by the hours worked. ${ }^{7}$ Descriptions of all variables, along with means and standard deviations, are provided in Appendix A.

\section{ASSIMILATION BY PRICES}

Table 1 presents the results from the regression analyses of the wages of adult male immigrants living in Australia, using data from the 2006 Australian Census. A number of specifications of the estimating equation were computed, and these differed in the way in which the Census information on the duration of stay in Australia (YSM) is utilized. As noted in

\footnotetext{
${ }^{6}$ See Barrett (2002) and Lee (2003). The comparisons in Lee (2003) between the estimates he obtained from a grouped regression model and those in studies that use OLS suggest that the two approaches yield similar results.

${ }^{7}$ There are only minor changes in the duration of residence effects recorded when weekly rather than hourly earnings are used as the dependent variable.
} 
Section III, this information is included in the Census unit record file in categorical form, with eleven year-of-arrival groups being distinguished. This detailed categorical information was used in preliminary estimations, though only the results from models based on a continuous YSM variable are reported. ${ }^{8}$ This continuous variable was formed using the mid-points of the intervals in the categorical data. It is used in quadratic form in the Table 1, column (i) specification, and in linear form in the column (ii) specification. The first four columns of Table 1 are for males, and the final four columns of results are for females. ${ }^{9}$ For each gender, the first two columns of results are for immigrants from the non-English-speaking countries and the final two columns of results are for immigrants from the English-speaking developed countries (ESDC).

The estimated effects associated with the control variables, other than years since migration, are broadly consistent with prior research (see, for example, Chiswick and Miller (1985) for Australia, and Ferrer and Riddell (2008) for Canada), and in the interests of brevity they will not be discussed here. Rather, the focus will be on the effects of 'years since migration'. Note that as their associated partial effects are often relatively small, each of the years since migration variables has been scaled (the linear term has been divided by 10 and the squared term has been divided by 100). The effects of the years since migration variables show contrasting outcomes for immigrants from non-English-speaking countries and those from the main English-speaking developed countries. The effects also differ between males and females.

\footnotetext{
${ }^{8}$ The full set of results is presented in a Supplementary Appendix, available from the authors.

${ }^{9}$ Note that these results are obtained using OLS, without any correction for selectivity in employment. This approach is preferred when there is weak identification of the selection equation. The Census data does not contain variables that we are confident will be valid, strong instruments. The similarities of the conclusions from the study of wages (which may be prone to selection bias) and the study of employment probabilities below (which are not subject to such bias) is reassuring.
} 


\section{Table 1}

Estimates of Determinants of the Natural Logarithm of Hourly Earnings among Employed Male and Female Immigrants who Arrived as Adults, Australia, 2006

\begin{tabular}{|c|c|c|c|c|c|c|c|c|}
\hline \multirow[b]{3}{*}{ Variable } & \multicolumn{4}{|c|}{$\underline{\text { Males }}$} & \multicolumn{4}{|c|}{ Females } \\
\hline & \multicolumn{2}{|c|}{ Non-ESDC } & \multicolumn{2}{|c|}{ ESDC } & \multicolumn{2}{|c|}{$\underline{\text { non-ESDC }}$} & \multicolumn{2}{|c|}{ ESDC } \\
\hline & (i) & (ii) & (i) & (ii) & (i) & (ii) & (i) & (ii) \\
\hline \multirow[t]{2}{*}{ Constant } & 1.993 & 2.000 & 1.785 & 1.785 & 1.972 & 1.972 & 1.922 & 1.923 \\
\hline & $(58.72)$ & (58.93) & $(42.34)$ & (42.34) & $(50.02)$ & (50.02) & $(38.06)$ & $(38.13)$ \\
\hline \multirow[t]{2}{*}{ Education } & 0.058 & 0.058 & 0.085 & 0.085 & 0.054 & 0.054 & 0.076 & 0.076 \\
\hline & $(34.02)$ & (33.78) & $(37.65)$ & (37.68) & (26.46) & (26.49) & (27.33) & (27.35) \\
\hline \multirow[t]{2}{*}{ Experience (EXPER) } & 0.024 & 0.019 & 0.024 & 0.024 & 0.017 & 0.017 & 0.018 & 0.018 \\
\hline & $(13.57)$ & (12.31) & (9.59) & (10.63) & $(8.40)$ & $(10.05)$ & $(6.36)$ & (7.53) \\
\hline \multirow[t]{2}{*}{ EXPER Squared/100 } & -0.038 & -0.027 & -0.037 & -0.037 & -0.031 & -0.031 & -0.034 & -0.035 \\
\hline & $(10.73)$ & (8.99) & $(8.15)$ & $(9.06)$ & $(7.26)$ & $(8.65)$ & (6.29) & (7.53) \\
\hline Speaks English Very & -0.111 & -0.118 & -0.085 & -0.085 & -0.048 & -0.048 & -0.095 & -0.096 \\
\hline Well/Well & (8.53) & $(9.08)$ & $(3.11)$ & $(3.11)$ & $(3.57)$ & $(3.57)$ & $(3.01)$ & (3.03) \\
\hline Speaks English Not & -0.251 & -0.263 & 0.100 & 0.100 & -0.193 & -0.193 & -0.093 & -0.097 \\
\hline Well/Not at All & $(12.84)$ & $(13.52)$ & $(0.54)$ & $(0.54)$ & $(9.00)$ & $(9.00)$ & $(0.15)$ & $(0.16)$ \\
\hline \multirow[t]{2}{*}{ Married } & 0.076 & 0.077 & 0.117 & 0.117 & -0.006 & -0.006 & -0.032 & -0.032 \\
\hline & (6.36) & $(6.50)$ & (8.61) & $(8.62)$ & $(0.47)$ & $(0.48)$ & $(2.20)$ & $(2.21)$ \\
\hline \multirow[t]{2}{*}{ Government Sector } & 0.237 & 0.236 & 0.074 & 0.074 & 0.190 & 0.190 & 0.037 & 0.037 \\
\hline & $(14.74)$ & $(14.71)$ & $(4.30)$ & $(4.30)$ & $(12.76)$ & (12.77) & $(2.23)$ & (2.23) \\
\hline Years Since & -0.070 & 0.022 & -0.024 & -0.024 & 0.076 & 0.072 & 0.040 & 0.025 \\
\hline Migration (YSM)/10 & $(4.09)$ & $(3.34)$ & $(1.28)$ & $(3.51)$ & $(3.67)$ & $(9.06)$ & $(1.70)$ & (3.11) \\
\hline YSM Squared/100 & $\begin{array}{l}0.025 \\
(5.85)\end{array}$ & (a) & $\begin{array}{c}0.000 \\
(0.02)\end{array}$ & (a) & $\begin{array}{c}0.001 \\
(0.25)\end{array}$ & (a) & $\begin{array}{c}-0.004 \\
(0.65)\end{array}$ & (a) \\
\hline Adjusted $R^{2}$ & 0.131 & 0.129 & 0.136 & 0.136 & 0.104 & 0.104 & 0.095 & 0.095 \\
\hline Sample Size & 17,873 & 17,873 & 12,388 & 12,388 & 14,566 & 14,566 & 9,526 & 9,526 \\
\hline
\end{tabular}

Notes: ' $\mathrm{t}$ ' statistics in parentheses; (a) = Variable not entered.

Source: Australian Census of Population and Housing, 2006, Census Sample File.

Consider males. The relationship between earnings and duration of stay in Australian among male immigrants from the non-English-speaking countries is characterized by an atypical pattern, in that the coefficient on the linear years since migration variable is negative (this is usually positive) and the coefficient on the quadratic term is positive (this is usually negative). Examination of the results for the more detailed specification based on the dichotomous immigrant arrival cohorts (see the Statistical Appendix) shows that this result is driven by the relatively strong labor market performance of those who arrived in Australia since 2000. This could reflect either greater self selection in migration in times of economic downturn, or the 
progressive tightening over the 1990s of the points system used to select skilled immigrants by Australia (see Chiswick and Miller, 2006). The summary provided by the linear duration of residence variable in column (ii) indicates that the earnings-duration relationship is positive, with earnings increasing at the rate of one-fifth of a percentage point per year of stay in Australia. Past research in Australia (e.g., Chiswick and Miller, 1985) has similarly reported quite weak price adjustment.

In the case of male immigrants from English-speaking countries (ESDC), a negative association between earnings and duration of stay is observed in both models. This offers evidence in support of the negative assimilation hypothesis (Chiswick and Miller, 2011). Based on the linear duration specification, there is a statistically significant decline in earnings, at the rate of 0.2 of one percentage point per year of residence in Australia. This negative assimilation effect in Australia is smaller than the results based on the 2000 US Census, where the comparative rate is a decline of around 0.7 of one percentage point per year of duration in the US (Chiswick and Miller, 2011).

Hence, the pattern of earnings adjustment of male immigrants in Australia shows weak negative assimilation for immigrants from the English-speaking developed countries and modest positive assimilation for those from the non-English-speaking countries. This is a muted version of the pattern observed in the US. This is consistent with the research by Antecol, Kuhn and Trejo (2006) and Miller and Neo (2003), where it is argued that due to the rigidity of the wage structure, immigrant adjustment in Australia is more through quantity adjustment (employment) than through price adjustment.

In the case of female immigrants from non-English-speaking countries, both the quadratic and linear models indicate significant positive assimilation in earnings. Based on the linear 
duration variable, their earnings improve at the rate of 0.7 of one percentage point per year. The positive earnings adjustment with duration of residence in Australia for women from nonEnglish-speaking countries is thus much stronger than that observed for men.

The results for the various measures of duration of stay in Australia indicate that there is also positive assimilation for earnings among female immigrants from English-speaking countries. The linear duration variable indicates an improvement of earnings at 0.3 of one percentage point per year in Australia.

Thus, the more positive earnings adjustment for female immigrants from non-Englishspeaking countries compared to males from those countries carries over to the analyses for women from the English-speaking countries, where the earnings-duration of residence effect is mildly positive for women and negative for men. A weaker negative earnings effect, or even a positive effect, is what would be expected where the sample of female immigrants from Englishspeaking countries includes a sizeable proportion of tied movers, for whom, as discussed in Section II, the negative assimilation model is not readily applicable, or is applicable only for the subset who were primary movers. We examine this matter further in Section VI. ${ }^{10}$

In summary, these analyses of the earnings data from the 2006 Australian Census provide evidence of weak positive earnings (price) assimilation among male immigrants from nonEnglish-speaking countries, and evidence of modest negative earnings (price) assimilation among male immigrants from English-speaking countries. Analysis of the earnings of female immigrants reveals evidence of stronger positive price assimilation among those from non-

${ }^{10}$ Of the recent adult immigrants who entered Australia on permanent skilled visas, 77 percent of males, but only 35 percent of females, were the primary visa applicant. Alternatively stated, among the main applicants, 70 percent were males, and among those who were not the main applicant, only 27 percent were males (see Australian Bureau of Statistics, 2011). 
English-speaking countries, whereas among female immigrants from English-speaking countries there is weak, positive assimilation. The findings are consistent with female immigrants from the ESDC being more likely to be tied movers than their economic migrant male counterparts.

\section{ASSIMILATION BY QUANTITIES}

The patterns of assimilation by quantities are examined in this section. In the first instance the index of adjustment will be the employment rate. This has previously been studied by Antecol et al. (2006), albeit without the distinction between immigrants from English-speaking and non-English-speaking countries. Following this, attention turns to the unemployment rate that formed the basis of the analyses by Miller and Neo (2003). Then the changes with duration of residence in hours worked among the employed will be examined.

\section{(a) Employment Assimilation}

Table 2 reports the analysis of the determinants of the probability of being employed (compared to being either unemployed or not in the labor force) among immigrants in Australia in 2006. The structure of this table is the same as that of Table 1 . While the dependent variable in these analyses is a dichotomous indicator of whether the individual was employed or not at the time of the Census, the analyses are undertaken using Ordinary Least Squares. The findings from this statistical approach do not differ in any material way from those obtained using non-linear binary choice models, and yet are easier to interpret. The results for the control variables, other than duration of residence, have interpretations consistent with those presented for the analyses of the determinants of earnings. The discussion that follows will focus on the estimated effects of duration of residence and country of origin on the probability of being employed. 
Table 2

\section{Estimates of Determinants of Employment among Male and Female Immigrants who Arrived as Adults, Australia, 2006}

\begin{tabular}{|c|c|c|c|c|c|c|c|c|}
\hline \multirow[b]{3}{*}{ Variable } & \multicolumn{4}{|c|}{ Males } & \multicolumn{4}{|c|}{ Females } \\
\hline & \multicolumn{2}{|c|}{ non-ESDC } & \multicolumn{2}{|c|}{ ESDC } & \multicolumn{2}{|c|}{$\underline{\text { non-ESDC }}$} & \multicolumn{2}{|c|}{ ESDC } \\
\hline & (i) & (ii) & (i) & (ii) & (i) & (ii) & (i) & (ii) \\
\hline Constant & $\begin{array}{c}-0.671 \\
(1809)\end{array}$ & $\begin{array}{c}-0.806 \\
357)\end{array}$ & 0.140 & 0.045 & $\begin{array}{r}-0.720 \\
\end{array}$ & -0.946 & $\begin{array}{r}-0.499 \\
(8.05)\end{array}$ & -0.666 \\
\hline Education & $\begin{array}{c}0.019 \\
(21.65)\end{array}$ & $\begin{array}{c}0.019 \\
(22.06)\end{array}$ & $\begin{array}{l}0.009 \\
(8.06)\end{array}$ & $\begin{array}{l}0.009 \\
(7.95)\end{array}$ & $\begin{array}{c}0.034 \\
(36.15)\end{array}$ & $\begin{array}{c}0.035 \\
(36.64)\end{array}$ & $\begin{array}{c}0.028 \\
(18.59)\end{array}$ & $\begin{array}{c}0.027 \\
(18.32)\end{array}$ \\
\hline Age & $\begin{array}{c}0.059 \\
(31.70)\end{array}$ & $\begin{array}{c}0.067 \\
(41.76)\end{array}$ & $\begin{array}{c}0.033 \\
(14.91)\end{array}$ & $\begin{array}{c}0.039 \\
(19.61)\end{array}$ & $\begin{array}{c}0.042 \\
(21.65)\end{array}$ & $\begin{array}{c}0.057 \\
(33.88)\end{array}$ & $\begin{array}{c}0.046 \\
(15.71)\end{array}$ & $\begin{array}{c}0.057 \\
(22.04)\end{array}$ \\
\hline Age Squared/100 & $\begin{array}{l}-0.073 \\
(34.47)\end{array}$ & $\begin{array}{c}-0.083 \\
(44.45)\end{array}$ & $\begin{array}{c}-0.044 \\
(18.05)\end{array}$ & $\begin{array}{c}-0.051 \\
(23.04)\end{array}$ & $\begin{array}{c}-0.053 \\
(23.35)\end{array}$ & $\begin{array}{l}-0.070 \\
(35.21)\end{array}$ & $\begin{array}{c}-0.060 \\
(18.35)\end{array}$ & $\begin{array}{l}-0.073 \\
(25.07)\end{array}$ \\
\hline Speaks English Very & -0.043 & -0.038 & -0.016 & -0.019 & -0.056 & -0.056 & -0.048 & -0.054 \\
\hline Well/Well & (5.75) & (5.19) & (1.14) & $(1.35)$ & $(7.35)$ & $(7.33)$ & $(2.61)$ & $(2.90)$ \\
\hline Speaks English Not & -0.216 & -0.209 & -0.192 & -0.199 & -0.250 & -0.247 & -0.111 & -0.136 \\
\hline Well/Not at All & (21.69) & (21.05) & $(2.25)$ & $(2.34)$ & (25.76) & (25.43) & $(0.35)$ & $(0.43)$ \\
\hline Married & $\begin{array}{c}0.104 \\
(16.31)\end{array}$ & $\begin{array}{c}0.102 \\
(15.98)\end{array}$ & $\begin{array}{c}0.080 \\
(11.96)\end{array}$ & $\begin{array}{c}0.078 \\
(11.67)\end{array}$ & $\begin{array}{c}-0.009 \\
(1.54)\end{array}$ & $\begin{array}{c}-0.016 \\
(2.57)\end{array}$ & $\begin{array}{c}-0.049 \\
(5.72)\end{array}$ & $\begin{array}{c}-0.052 \\
(6.05)\end{array}$ \\
\hline Years Since & 0.112 & 0.033 & 0.054 & -0.031 & 0.185 & 0.047 & 0.130 & 0.029 \\
\hline Migration (YSM)/10 & (12.19) & $(9.36)$ & $(5.80)$ & $(0.95)$ & $(18.75)$ & $(12.52)$ & $(10.08)$ & $(6.34)$ \\
\hline YSM Squared/100 & $\begin{array}{r}-0.020 \\
(9.31)\end{array}$ & (a) & $\begin{array}{r}-0.014 \\
(6.56)\end{array}$ & (a) & $\begin{array}{c}-0.036 \\
(15.12)\end{array}$ & (a) & $\begin{array}{c}-0.026 \\
(8.39)\end{array}$ & (a) \\
\hline Adjusted $R^{2}$ & 0.160 & 0.158 & 0.106 & 0.104 & 0.156 & 0.150 & 0.094 & 0.090 \\
\hline Sample Size & 26,475 & 26,475 & 15,434 & 15,434 & 30,294 & 30,294 & 15,036 & 15,036 \\
\hline
\end{tabular}

Notes: 't' statistics in parentheses; $(\mathrm{a})=$ Variable not entered.

Source: Australian Census of Population and Housing, 2006, Census Sample File.

The Table 2 column (i) specification for male immigrants from non-English-speaking countries reveals that there is strong, positive employment assimilation. Thus, in the quadratic specification, the positive coefficient on the linear duration variable is quite sizeable, and the negative coefficient on the squared term is more modest. Using the linear variable as an over-all summary of the employment probability-duration of residence relationship, Table 2 column (ii) indicates that there is an improvement in the probability of being employed of around one-third of a percentage point per extra year of residence in Australia.

The findings for the employment adjustment of male immigrants from English-speaking countries diverge from those for their counterparts from non-English-speaking countries. The 
quadratic specification for the duration of residence information is characterized by a positive coefficient on the linear term (which is one-half of the size of the coefficient for the non-Englishspeaking immigrants sample), and by a relatively more sizeable negative coefficient on the squared term (which is two-thirds the size of the respective coefficient for the non-Englishspeaking immigrants sample). When the relationship between the probability of employment and the duration of residence in Australia is summarized using a single linear duration of residence variable, the estimated coefficient is statistically insignificant.

Hence, the general pattern that emerges from the Table 2 analyses of the employment probability of adult male immigrants is one of pronounced, positive employment assimilation among immigrants from non-English-speaking countries, and negligible (negative) employment assimilation among immigrants from English-speaking countries. These findings are for a labor market where the relatively high degree of wage rigidity is likely to make positive employment assimilation a more likely outcome (Miller and Neo, 2003; Cobb-Clark and Crossley, 2004).

The findings for female immigrants from non-English-speaking countries are an accentuated version of the results for male immigrants from these countries. Hence, the estimated coefficient on the linear years since migration variable is almost twice the size of that reported for their male counterparts. Thus, in parallel with the study of wage assimilation, the positive employment assimilation is also more intense for females than for males.

Female immigrants from English-speaking countries are also characterized by positive employment assimilation, but this is weaker than is the case for their counterparts from nonEnglish-speaking countries. In particular, the average improvement in the employment probability would only be around one-half as large for female immigrants from English-speaking countries as it is for female immigrants from other countries. 
Thus, both groups of female immigrants are characterized by positive employment assimilation, but this assimilation is much weaker among immigrants from English-speaking countries than it is among other female immigrants.

\section{(b) Unemployment Assimilation}

Table 3 presents the results from the analysis of the incidence of unemployment among those in the paid labor force. The model used here is the same as that adopted for the study of the employment probability, although the samples for the current sets of analyses are restricted to those in the labor force (i.e., are employed or unemployed).

\section{Table 3}

\section{Estimates of Determinants of Unemployment among Male and Female Immigrants who Arrived as Adults and who Participate in the Labor Force, Australia, 2006}

\begin{tabular}{|c|c|c|c|c|c|c|c|c|}
\hline \multirow{3}{*}{ Variable } & \multicolumn{4}{|c|}{ Males } & \multicolumn{4}{|c|}{ Females } \\
\hline & \multicolumn{2}{|c|}{ non-ESDC } & \multicolumn{2}{|c|}{ ESDC } & \multicolumn{2}{|c|}{ non-ESDC } & \multicolumn{2}{|c|}{ ESDC } \\
\hline & (i) & (ii) & (i) & (ii) & (i) & (ii) & (i) & (ii) \\
\hline \multirow[t]{2}{*}{ Constant } & 0.444 & 0.461 & 0.162 & 0.180 & 0.404 & 0.459 & 0.157 & 0.180 \\
\hline & $(15.52)$ & $(17.47)$ & $(6.02)$ & $(7.02)$ & $(11.57)$ & (14.17) & $(4.74)$ & $(5.77)$ \\
\hline \multirow[t]{2}{*}{ Education } & -0.005 & -0.005 & -0.003 & -0.003 & -0.006 & -0.006 & -0.005 & -0.005 \\
\hline & (7.94) & $(8.02)$ & $(4.49)$ & $(4.44)$ & $(8.12)$ & $(8.22)$ & $(6.29)$ & (6.24) \\
\hline \multirow[t]{2}{*}{ Age } & -0.013 & -0.014 & -0.004 & -0.005 & -0.007 & -0.011 & -0.001 & -0.003 \\
\hline & $(8.97)$ & (11.14) & $(2.90)$ & $(4.23)$ & $(4.11)$ & (7.08) & $(0.68)$ & $(1.88)$ \\
\hline \multirow[t]{2}{*}{ Age Squared/100 } & 0.015 & 0.016 & 0.005 & 0.006 & 0.007 & 0.012 & 0.001 & 0.003 \\
\hline & $(9.15)$ & (11.27) & (3.49) & (4.89) & $(3.41)$ & $(6.17)$ & $(0.63)$ & (1.83) \\
\hline Speaks English Very & 0.013 & 0.012 & 0.002 & 0.003 & 0.017 & 0.016 & 0.038 & 0.039 \\
\hline Well/Well & $(2.47)$ & $(2.36)$ & $(0.28)$ & $(0.35)$ & $(2.88)$ & (2.73) & $(4.05)$ & $(4.12)$ \\
\hline Speaks English Not & 0.068 & 0.067 & -0.044 & -0.043 & 0.113 & 0.111 & -0.093 & -0.088 \\
\hline Well/Not at All & (9.09) & (8.99) & $(0.80)$ & $(0.77)$ & (12.96) & $(12.82)$ & $(0.48)$ & $(0.45)$ \\
\hline \multirow[t]{2}{*}{ Married } & -0.049 & -0.049 & -0.032 & -0.032 & -0.025 & -0.024 & -0.017 & -0.017 \\
\hline & $(10.74)$ & (10.69) & $(8.26)$ & $(8.18)$ & $(5.08)$ & $(4.88)$ & $(3.92)$ & (3.88) \\
\hline Years Since & -0.030 & -0.020 & -0.013 & -0.002 & -0.064 & -0.030 & -0.020 & -0.007 \\
\hline Migration (YSM)/10 & $(4.54)$ & $(7.95)$ & $(2.44)$ & $(1.18)$ & $(7.45)$ & (9.18) & $(2.95)$ & $(2.81)$ \\
\hline YSM Squared/100 & $\begin{array}{l}0.003 \\
(1.56)\end{array}$ & (a) & $\begin{array}{c}0.003 \\
(2.16)\end{array}$ & (a) & $\begin{array}{c}0.009 \\
(4.24)\end{array}$ & (a) & $\begin{array}{c}0.004 \\
(2.09)\end{array}$ & (a) \\
\hline Adjusted $R^{2}$ & 0.032 & 0.032 & 0.010 & 0.010 & 0.042 & 0.041 & 0.008 & 0.007 \\
\hline Sample Size & 21,056 & 21,056 & 13,692 & 13,692 & 17,613 & 17,613 & 10,732 & 10,732 \\
\hline
\end{tabular}

Notes: 't' statistics in parentheses; (a) = Variable not entered.

Source: Australian Census of Population and Housing, 2006, Census Sample File. 
Among male immigrants from non-English-speaking countries, the unemployment probability declines with length of stay in Australia (see Table 3, columns (i) and (ii)). The decline is by about 0.2 of a percentage point per year. In other words, among this group of immigrants, there is positive assimilation by quantities when the incidence of unemployment is used as the index of adjustment. Among male immigrants from English-speaking countries, the incidence of unemployment also declines with length of stay in Australia, though the downward adjustment is negligible in size, and statistically insignificant.

The findings for female immigrants from the study of the probability of being unemployed inform on a, by now, compelling story. Female immigrants from non-Englishspeaking countries are characterized by more pronounced reductions in the probability of being unemployed with increases in their duration in Australia. That is, the analysis of the determinants of unemployment among female immigrants from non-English-speaking countries reveals evidence consistent with strong, positive employment assimilation. The coefficient on the linear duration variable indicates that the incidence of unemployment declines by 0.3 of a percentage point per year of residence in Australia, an effect 50 percent greater than the impact among their male counterparts.

Turning to the results for female immigrants from English-speaking countries, it is apparent that there are modest reductions in the probability of unemployment with increases in the length of stay in Australia. The summary of the effects of duration of residence on the probability of being unemployed provided by the coefficient on the linear duration of residence variable indicates that this relationship is negative, statistically significant, but quite weak: The estimated coefficient is only -0.001 . 


\section{(c) Hours Worked Assimilation}

The final set of analyses, reported in Table 4, cover the determinants of hours worked among employed immigrants. Thus, the sample used here is the same as that used for the study of hourly wages in Table 1, and without correction for selectivity in employment. The hourly wage data were constructed by dividing the weekly income by hours worked. Hence, in principle, evidence of minimal hourly wage assimilation among immigrants from non-Englishspeaking countries could arise from off-setting growth in weekly earnings and in their weekly hours of work with duration in Australia. Similarly, the evidence of negative hourly wage assimilation among immigrants from English-speaking countries could be attributable to either a decline in their weekly earnings or an increase in their weekly hours of work with duration of residence in Australia.

The evidence in Table 4 for males, for the control variables, is consistent with expectations. The better educated, those with more general labor market experience (at least up to around 25 years of labor market activity), those most proficient in English, the married, and workers in the private sector, all supply more labor than their counterparts. Male immigrants from non-English-speaking countries increase their hours of work with duration in Australia; according to the linear specification in Table 4 column (ii), hours of work per week increase by around two-fifths of a percentage point per year in Australia. This positive hours of work assimilation occurs simultaneously with the minor hourly wage adjustment documented earlier. In other words, there is a gently upward sloping labor supply (hours worked) curve.

In the case of male immigrants from English-speaking countries, the results for the linear duration of residence specification in Table 4 reveal there is negligible hours of work 
assimilation. This negligible hours of work adjustment occurs simultaneously with the negative hourly wage adjustment that was reported in Table 1.

Table 4

Estimates of Determinants of the Natural Logarithm of Hours Worked among Employed Male and Female Immigrants who Arrived as Adults, Australia, 2006

\begin{tabular}{|c|c|c|c|c|c|c|c|c|}
\hline \multirow[b]{3}{*}{ Variable } & \multicolumn{4}{|c|}{$\underline{\text { Males }}$} & \multicolumn{4}{|c|}{ Females } \\
\hline & \multicolumn{2}{|c|}{ non-ESDC } & \multicolumn{2}{|c|}{ ESDC } & \multicolumn{2}{|c|}{ non-ESDC } & \multicolumn{2}{|c|}{ ESDC } \\
\hline & (i) & (ii) & (i) & (ii) & (i) & (ii) & (i) & (ii) \\
\hline \multirow[t]{2}{*}{ Constant } & 3.144 & 3.140 & 3.502 & 3.502 & 2.929 & 2.928 & 3.291 & 3.292 \\
\hline & (124.13) & (124.03) & (118.92) & (118.91) & (76.43) & (76.35) & $(67.11)$ & $(67.20)$ \\
\hline \multirow[t]{2}{*}{ Education } & 0.008 & 0.008 & 0.004 & 0.004 & 0.017 & 0.017 & 0.015 & 0.015 \\
\hline & $(6.21)$ & (6.37) & $(2.75)$ & (2.67) & $(8.42)$ & $(8.60)$ & $(5.50)$ & $(5.48)$ \\
\hline \multirow[t]{2}{*}{ Experience (EXPER) } & 0.024 & 0.027 & 0.015 & 0.016 & 0.012 & 0.018 & 0.005 & 0.006 \\
\hline & (18.30) & (23.62) & $(8.55)$ & $(10.51)$ & $(6.27)$ & $(10.58)$ & $(1.86)$ & $(2.35)$ \\
\hline \multirow[t]{2}{*}{ EXPER Squared/100 } & -0.046 & -0.051 & -0.033 & -0.036 & -0.022 & -0.033 & -0.015 & -0.016 \\
\hline & (17.36) & (22.68) & $(10.41)$ & (12.64) & $(5.41)$ & (9.46) & $(2.86)$ & $(3.52)$ \\
\hline Speaks English Very & -0.062 & -0.059 & 0.018 & 0.017 & -0.013 & -0.008 & 0.026 & 0.026 \\
\hline Well/Well & $(6.40)$ & $(6.08)$ & $(0.95)$ & $(0.88)$ & $(0.96)$ & $(0.63)$ & $(0.85)$ & $(0.83)$ \\
\hline Speaks English Not & -0.119 & -0.114 & -0.365 & -0.368 & -0.064 & -0.058 & 0.340 & 0.338 \\
\hline Well/Not at All & (8.19) & (7.83) & (2.81) & $(2.84)$ & (3.09) & $(2.76)$ & $(0.58)$ & $(0.57)$ \\
\hline \multirow[t]{2}{*}{ Married } & 0.091 & 0.091 & 0.053 & 0.053 & 0.015 & 0.012 & -0.131 & -0.131 \\
\hline & (10.29) & $(10.20)$ & (5.61) & (5.54) & $(1.24)$ & $(1.06)$ & $(9.31)$ & $(9.32)$ \\
\hline \multirow[t]{2}{*}{ Government Sector } & -0.024 & -0.024 & -0.056 & -0.056 & 0.019 & 0.020 & 0.051 & 0.051 \\
\hline & $(2.02)$ & $(2.01)$ & $(4.62)$ & (4.62) & $(1.34)$ & (1.39) & (3.14) & (3.14) \\
\hline Years Since & 0.082 & 0.038 & 0.024 & -0.003 & 0.113 & 0.017 & -0.003 & -0.013 \\
\hline Migration (YSM)/10 & $(6.40)$ & (7.61) & $(1.80)$ & $(0.56)$ & $(5.60)$ & (2.19) & $(0.15)$ & $(1.69)$ \\
\hline \multirow[t]{2}{*}{ YSM Squared/100 } & -0.012 & (a) & -0.007 & (a) & -0.027 & (a) & -0.003 & (a) \\
\hline & $(3.73)$ & & $(2.15)$ & & (5.15) & & $(0.47)$ & \\
\hline Adjusted $R^{2}$ & 0.066 & 0.065 & 0.029 & 0.029 & 0.018 & 0.017 & 0.023 & 0.023 \\
\hline Sample Size & 17,873 & 17,873 & 12,388 & 12,388 & 14,566 & 14,566 & 9,526 & 9,526 \\
\hline
\end{tabular}

Notes: ' $t$ ' statistics in parentheses; (a) = Variable not entered.

Source: Australian Census of Population and Housing, 2006, Census Sample File.

Table 4 also reports the findings from the companion set of analyses for female immigrants. Among female immigrants from non-English-speaking countries, the coefficients on the arrival cohort variables in the Table 4 column (i) specification indicate positive hours of work adjustment for the first 20 years in Australia. Beyond this threshold, however, hours worked per week decline with residence in Australia. The linear years since migration variable has a positive, statistically significant, coefficient of 0.002. In comparison to this inverted ' $U$ '- 
shaped pattern, the hours worked per week by female immigrants from the English-speaking countries tend to decline with duration in Australia, though the ' $\mathrm{t}$ ' statistic on the negative coefficient is only 1.69 .

Overall, the study of the determinants of hours of work for females shows that the pattern for immigrants from non-English-speaking countries is consistent with the conventional inverted 'U'-shaped positive assimilation trajectory, whereas that for immigrants from English-speaking developed countries shows that hours worked decline with duration in Australia.

Given these patterns in the hours of work adjustment with duration of residence in Australia, the earnings analyses presented earlier were repeated using the natural logarithm of weekly earnings as the dependent variable. When the natural logarithm of hours worked was included as an explanatory variable, it had a coefficient of around 0.6, and the findings are very similar to those reported in Table $1 .{ }^{11}$ In the Supplementary Appendix, results from regressions estimated on weekly earnings without the hours worked regressor are reported. Table 5 presents the estimated coefficient from the linear years since migration variable from the separate estimations of the determinations of usual weekly earnings, together with the estimates for this variable from the analyses of hourly earnings and hours worked per week. ${ }^{12}$ Presenting the estimates from these three models together seems to be informative. For comparison purposes, the coefficients for the education variable are also presented.

Among male immigrants from non-English-speaking countries (Table 5), some minor price adjustment occurs via hourly earnings, and is reinforced by a labor supply effect on hours

\footnotetext{
${ }^{11}$ The low coefficient on the natural log of hours worked (elasticity of 0.6 ) is consistent with substantial measurement error in the hours variable.

${ }^{12}$ Recall that the three dependent variables are related: $\ln$ (hourly earnings) $=\ln$ (weekly earnings) - $\ln$ (hours per week).
} 
worked. As a result positive price adjustment is more apparent when weekly earnings are examined than when the focus in on hourly earnings. Among male immigrants from Englishspeaking countries, there is negative price adjustment when hourly earnings are examined, and trivial negative adjustment via hours worked. Consequently, when weekly earnings are examined, there remains the evidence of negative adjustment.

\section{Table 5}

\section{Selected Estimates of Determinants of the Natural Logarithm of Weekly Earnings, Natural Logarithm of Hourly Earnings and the Natural Logarithm of Weekly Hours Worked Among Employed Immigrants who arrived as Adults, by Gender, Australia, 2006}

\begin{tabular}{|lcccccc|}
\hline \multirow{2}{*}{ Variable } & \multicolumn{2}{c}{ non-English-speaking countries } & \multicolumn{3}{c|}{ English-speaking developed countries } \\
\cline { 2 - 7 } & $\begin{array}{c}\text { Weekly } \\
\text { Earnings }\end{array}$ & $\begin{array}{c}\text { Hourly } \\
\text { Earnings }\end{array}$ & $\begin{array}{c}\text { Hours } \\
\text { Worked }\end{array}$ & $\begin{array}{c}\text { Weekly } \\
\text { Earnings }\end{array}$ & $\begin{array}{c}\text { Hourly } \\
\text { Earnings }\end{array}$ & $\begin{array}{c}\text { Hours } \\
\text { Worked }\end{array}$ \\
\hline Males & & & & & & \\
Education & 0.066 & 0.058 & 0.008 & 0.090 & 0.085 & 0.004 \\
& $(36.58)$ & $(33.78)$ & $(6.37)$ & $(38.40)$ & $(37.68)$ & $(2.67)$ \\
Years Since & 0.060 & 0.022 & 0.038 & -0.027 & -0.024 & -0.003 \\
Migration (YSM)/10 & $(8.56)$ & $(3.34)$ & $(7.61)$ & $(3.79)$ & $(3.51)$ & $(0.56)$ \\
& & & & & & \\
Females & & & & & & \\
Education & 0.071 & 0.054 & 0.017 & 0.090 & 0.076 & 0.015 \\
& $(31.73)$ & $(26.49)$ & $(8.60)$ & $(29.05)$ & $(27.35)$ & $(5.48)$ \\
Years Since & 0.088 & 0.072 & 0.017 & 0.012 & 0.025 & -0.013 \\
Migration (YSM)/10 & $(10.19)$ & $(9.06)$ & $(2.19)$ & $(1.30)$ & $(3.11)$ & $(1.69)$ \\
\hline
\end{tabular}

Note: 't' statistics in parentheses.

Source: Australian Census of Population and Housing, 2006, Census Sample File.

Among female immigrants, there is evidence of positive price adjustment among those from English-speaking countries and those from non-English-speaking countries when the index of adjustment is the hourly rate of pay. The Table 5 evidence shows that the hours worked by female immigrants from non-English-speaking countries increase slightly with increases in the length of time they have resided in Australia, whereas the hours worked by female immigrants from English-speaking countries decline slightly with length of residence in Australia. This negative labor supply effect combines with the modest nature of the positive hourly wage effect 
to result in a statistically insignificant relationship between the weekly earnings and duration in Australia for female immigrants from English-speaking countries. In contrast, the relationship between the weekly earnings and duration of residence in Australia for female immigrants from non-English-speaking countries is positive.

Hence, when the focus is on weekly rather than hourly earnings, there is evidence of negative earnings assimilation among male immigrants from English-speaking countries, and negligible price adjustment among female immigrants from these countries. This sits side-byside with the strong positive earnings adjustment of both male and female immigrants from nonEnglish-speaking countries.

\section{SENSITIVITY ANALYSIS}

Two issues are investigated in this section. The first is whether the findings for female immigrants are sensitive to the use of the limited information available on whether they are tied or economic migrants. The second issue relates to whether the results are sensitive to the way the population of immigrants who arrived in Australia as adults is measured.

\section{(A) Motive for Migration Among Females}

Differences in findings for male and female immigrants could reflect a greater proportion of tied immigrants among females. The census data does not, however, contain information on the motive for migration. Nevertheless, it is possible that some insight into this can be gained through the use of the census marital status information, in conjunction with information on the birthplace of the oldest child in the family home. Hence, foreign-born females who arrived in Australia as an adult and who were listed as never married at the time of the census were categorized as economic immigrants. Foreign-born females who were, or had been, married at 
the time of the census and whose oldest child (still living at home) was born abroad were categorized as tied immigrants. ${ }^{13}$ These two groups comprise, respectively, 17 percent and 19 percent of the sample of adult female immigrants from non-English-speaking countries, and 20 and 19 percent of those from English-speaking countries. All other foreign-born female immigrants have their motive for migration categorized as 'unsure'. Dichotomous variables for 'unsure' and 'tied' were entered into the earnings equation (the reference group is 'economic' immigrants), together with interaction terms between these dichotomous variables and the linear years since migration variable. Selected results are presented in Table 6.

\section{Table 6}

\section{Selected Regression Coefficients of Model of Earnings Determination for Adult Female Immigrants with Motive for Migration Variables ${ }^{(a)}$}

\begin{tabular}{|lcc|}
\hline Variable & Non-English Speaking Countries & English-Speaking Countries \\
\hline Years Since Migration & $\mathbf{0 . 2 4 2}$ & $\mathbf{- 0 . 0 2 3}$ \\
(YSM)/10 & $\mathbf{( 1 1 . 8 7 )}$ & $\mathbf{( 1 . 1 3 )}$ \\
Tied Immigrant & 0.088 & -0.350 \\
& $(2.54)$ & $(8.62)$ \\
Unsure of Motive for & 0.200 & -0.148 \\
Migration & $(7.19)$ & $(4.35)$ \\
YSM/10 * Tied & -0.132 & 0.100 \\
& $(5.38)$ & $(3.64)$ \\
YSM/10 * Unsure & -0.186 & 0.013 \\
& $(9.26)$ & $(0.62)$ \\
\hline
\end{tabular}

(a) Benchmark is 'economic migrants', as defined in the text.

Source: Australian Census of Population and Housing, 2006, Census Sample File.

Among female immigrants from non-English-speaking countries, the ranking of earnings at the time of arrival, from highest to lowest, is 'unsure', 'tied' and 'economic'. Economic immigrants are characterized by strong earnings growth with length of residence in Australia,

\footnotetext{
${ }^{13}$ There is no information available in the census on year or age at current or first marriage or on children who do not live with their parents.
} 
whereas the earnings growth for the other two groups, whilst positive, is much more modest. This suggests that the initial earnings disadvantage of economic immigrants is a result of their post-arrival investment in destination-specific human capital. As a result of this investment, after around 11 years of residence in Australia, the female economic immigrants have higher earnings than the other two motive-for-migration groups of women.

In contrast, among female immigrants from English-speaking countries, the ranking of earnings at the time of arrival, from highest to lowest, is 'economic', 'unsure' and 'tied'. The earnings of economic immigrants are characterized by a decline, albeit insignificant, with duration of residence in Australia, whereas the 'tied' group, which has the lowest earnings at arrival, is characterized by significant earnings growth with duration in Australia.

Hence, thought the categorization of female immigrants according to motive for migration is crude, the findings for the economic immigrants are more aligned with the predictions of the positive (for immigrants from non-English-speaking countries) and negative (for immigrants from English-speaking countries) assimilation models than the analyses conducted using the data pooled across all female migrants. The collection of data on visa status at entry and motive for migration would assist further research endeavors.

(B) Sensitivity to Age at Migration

Turning to the second test of robustness, it is noted that the sample of immigrants who arrived in Australia as adults may be defined imprecisely, due to the fact that an age at migration has to be inferred from the census self reports on age and year of arrival in Australia, and the year of arrival information is presented only in 5-year bands. To examine the effect that this coarse nature of the measure of age at migration might have on the analyses, the analyses of hourly and weekly earnings, employment, unemployment and hours worked were undertaken on 
two further populations: the sub-set of immigrants who arrived in Australia at age 18 or more, and the sample of all immigrants (that is, those who arrived as children as well as those who arrived as adults). The immigrants who arrived in Australia aged more than 18 years comprise around 58 percent of the total sample, whereas those who arrived in Australia aged more than 15 years are about 64 percent of the initial sample. Relevant findings in relation to the linear years since migration variables for the three samples are reported in Table 7 . These results relate to the five labor outcomes: hourly earnings, employment, unemployment, hours worked and weekly earnings. The full set of results is a statistical appendix, which is available from the authors upon request.

The estimated coefficients indicate that there is only one outcome for immigrants from non-English-speaking countries which appears to be sensitive to the composition of the sample. Thus, among adult male immigrants from non-English-speaking countries who were more than 18 years at the time of arrival, the years since migration effect is statistically insignificant in the hourly earnings equation. It remains statistically significant in the weekly earnings equation, and the labor supply indices are also characterized by strong positive assimilation. One would therefore conclude from the complete set of results for adult immigrants from non-Englishspeaking countries that their labor market outcomes are characterized by positive assimilation, and that this adjustment profile is stronger for females than for males.

Among immigrants from English-speaking countries, the main change observed as the sample is narrowed from all immigrants to adult immigrants is a weakening of the negative quantity assimilation that characterizes the adjustment of males with increases in their length of residence in Australia. To generate this change, compared to adult immigrants, those who arrived as children must have either high hours worked/employment probabilities among recent arrivals, 
or low hours worked/employment probabilities among longer-term settlers. This would also appear to be the case among female immigrants from English-speaking countries. As immigrants who arrived as children should, given the age restriction on the sample (20-64 years), not greatly impact the results for recent arrivals, the change in the Table 7 results between all immigrants and adult immigrants must imply that immigrants who arrived as children and who are in the longer duration of residence categories have relatively low weekly hours worked.

Table 7

Estimated Relationship Between Labor Market Outcomes and Linear Duration of
Residence Variable $^{(\text {a) }}$, All Immigrants and Adult Immigrants By Gender, Australia 2006

\begin{tabular}{|c|c|c|c|c|c|c|}
\hline Dependent Variable & \multicolumn{3}{|c|}{ Non-English-speaking countries } & \multicolumn{3}{|c|}{ English-speaking developed countries } \\
\hline & & Adult & Adult & & Adult & Adult \\
\hline A. Males & $\begin{array}{c}\text { All } \\
\text { Immigrants }\end{array}$ & $\begin{array}{c}\text { Immigrants } \\
(>15)\end{array}$ & $\begin{array}{c}\text { Immigrants } \\
\quad(>18)\end{array}$ & $\begin{array}{c}\text { All } \\
\text { Immigrants }\end{array}$ & $\begin{array}{c}\text { Immigrants } \\
\quad(>15)\end{array}$ & $\begin{array}{c}\text { Immigrants } \\
\quad>18)\end{array}$ \\
\hline 1. Hourly Earnings & 0.039 & 0.022 & 0.007 & -0.016 & -0.024 & -0.023 \\
\hline & $(10.87)$ & (3.34) & $(0.98)$ & $(4.83)$ & (3.51) & (3.04) \\
\hline 2. Employment & 0.027 & 0.033 & 0.029 & -0.009 & -0.003 & 0.001 \\
\hline & (13.68) & (9.36) & $(7.44)$ & $(5.30)$ & $(0.95)$ & $(0.22)$ \\
\hline 3. Unemployment & -0.013 & -0.020 & -0.019 & 0.000 & -0.002 & -0.004 \\
\hline & $(9.21)$ & (7.95) & $(6.45)$ & $(0.12)$ & (1.18) & (1.93) \\
\hline 4. Hours Worked & 0.034 & 0.038 & 0.032 & -0.006 & -0.003 & -0.000 \\
\hline & (12.64) & (7.61) & $(5.82)$ & $(2.51)$ & $(0.56)$ & $(0.05)$ \\
\hline 5. Weekly Earnings & 0.074 & 0.060 & 0.040 & -0.022 & -0.027 & -0.023 \\
\hline & $(19.46)$ & (8.56) & (4.99) & $(6.42)$ & (3.79) & (2.99) \\
\hline Sample Size & 26,716 & 17,873 & 15,953 & 19,823 & 12,388 & 11,509 \\
\hline \multicolumn{7}{|l|}{ B. Females } \\
\hline 1. Hourly Earnings & 0.063 & 0.072 & 0.059 & 0.014 & 0.025 & 0.034 \\
\hline & (15.35) & $(9.06)$ & $(6.62)$ & $(3.42)$ & (3.11) & (3.19) \\
\hline 2. Employment & 0.046 & 0.047 & 0.050 & 0.012 & 0.029 & 0.035 \\
\hline & $(21.17)$ & (12.52) & (11.84) & (5.19) & (6.34) & $(6.96)$ \\
\hline 3. Unemployment & -0.020 & -0.030 & -0.031 & -0.003 & -0.007 & -0.010 \\
\hline & (12.59) & (9.18) & (8.16) & $(2.72)$ & (2.81) & (3.69) \\
\hline 4. Hours Worked & 0.006 & 0.017 & 0.012 & -0.024 & -0.013 & -0.014 \\
\hline & $(1.41)$ & (2.19) & (1.37) & (5.96) & (1.69) & (1.66) \\
\hline \multirow[t]{2}{*}{ 5. Weekly Earnings } & 0.068 & 0.088 & 0.071 & -0.010 & 0.012 & 0.014 \\
\hline & (15.19) & (10.19) & (7.27) & $(2.30)$ & (1.30) & $(1.40)$ \\
\hline Sample Size & 21,851 & 14,566 & 12,985 & 15,930 & 9,526 & 8,681 \\
\hline
\end{tabular}

Notes: (a)=duration of residence variable divided by 10; numbers of observations listed in the table are based on the samples for the earnings regressions. Regression results in columns in bold are from Tables 1 to 5 for those who immigrated at more than 15 years of age.

Source: Australian Census of Population and Housing, 2006, Census Sample File. 


\section{CONCLUSION}

Among economic migrants, immigrant adjustment with duration in a destination is expected to differ depending on whether the immigrants are from countries where skills are highly transferable to the destination or from low-skill transferability countries. Among immigrants from low skill transferability countries, positive economic adjustment is expected, as evidenced by improvements with duration in the destination in hourly and weekly earnings, increases in the employment probability and hours worked per week, and decreases in the probability of unemployment. Among economic migrants from very high skill transferability countries, however negative economic adjustment is expected. Hence, for these immigrants it is expected that with increases in duration their hourly and weekly earnings will decline, their probability of being employed and hours worked per week will decline, and the probability of being unemployed will increase. These hypotheses should generally apply to male immigrants who as primary movers are predominantly economic migrants. The extent to which they apply to female immigrants, who are likely to include a sizeable proportion of tied movers, is unclear.

The statistical tests are performed on the microdata from the 2006 Census of Australia for whom immigrants from the English-speaking developed countries (ESDC) have highly transferable skills. A summary of the evidence is presented in Table 8.

The results for male immigrants match these expectations. Male immigrants' economic outcomes are characterized by both price and quantity adjustment, and the two dimensions of adjustment display highly consistent patterns. The ESDC male immigrants exhibit negative earnings and employment assimilation while other male immigrants exhibit positive assimilation.

Among female immigrants from non-English-speaking countries, the dominant postarrival profile is one of positive economic adjustment, according to both the price and quantity 
dimensions. This adjustment is generally even more positive than that which characterized their male counterparts. The post-arrival path of economic adjustment for female immigrants from English-speaking developed countries is generally (though certainly not always) positive, but far weaker than that for female immigrants from non-English-speaking countries. The analyses conducted on a group of female immigrants who were likely to be economic immigrants (adult females who were never married at the time of the census) generated results that were consistent with the positive assimilation model for those from non-English-speaking countries, and with the negative assimilation model for those from English-speaking countries.

Hence, in Australia there is both positive assimilation and negative assimilation (when the skills are highly transferrable) via price (earnings) and quantity (employment) adjustments, and the two processes are highly consistent and robust.

Table 8

Summary of Assimilation Profiles by Prices and Quantities

\begin{tabular}{|c|c|c|c|c|}
\hline \multirow[b]{2}{*}{$\begin{array}{l}\text { Type of } \\
\text { Assimilation }\end{array}$} & \multicolumn{2}{|c|}{ Males } & \multicolumn{2}{|c|}{ Females } \\
\hline & $\begin{array}{l}\text { non-English- } \\
\text { speaking } \\
\text { countries }\end{array}$ & $\begin{array}{l}\text { English- } \\
\text { speaking } \\
\text { developed } \\
\text { countries }\end{array}$ & $\begin{array}{l}\text { non-English- } \\
\text { speaking } \\
\text { countries }\end{array}$ & $\begin{array}{l}\text { English- } \\
\text { speaking } \\
\text { developed } \\
\text { countries }\end{array}$ \\
\hline \multicolumn{5}{|c|}{ Assimilation by Prices } \\
\hline Wage & Modest positive & Modest negative & Stronger positive & Weak positive \\
\hline \multicolumn{5}{|c|}{ Assimilation by Quantities } \\
\hline Employed & Strong positive & Weak negative & Stronger positive & Weak positive \\
\hline Unemployed & Strong positive & $\begin{array}{l}\text { Negligible or } \\
\text { Modest negative }\end{array}$ & Stronger positive & Weak positive \\
\hline $\begin{array}{l}\text { Hours Worked } \\
\text { Per Week }\end{array}$ & $\begin{array}{l}\text { Traditional } \\
\text { inverted ' } U \text { ' } \\
\text { shape or modest } \\
\text { positive }\end{array}$ & Modest negative & $\begin{array}{l}\text { Traditional } \\
\text { inverted 'U' shape } \\
\text { or modest positive }\end{array}$ & $\begin{array}{l}\text { Modest } \\
\text { negative }\end{array}$ \\
\hline
\end{tabular}




\section{REFERENCES}

Antecol, Heather, Kuhn, Peter and Trejo, Stephen J., (2006). “Assimilation via Prices or Quantities? Sources of Immigrant Earnings Growth in Australia, Canada, and the United States”, The Journal of Human Resources, Vol. 41, No. 4, pp. 821-840.

Australian Bureau of Statistics, (2011). Characteristics of Recent Migrants, Australia, Nov 2010, Catalogue No. 6250.0.

Baker, Michael and Dwayne Benjamin, (1997). “The Role of Family in Immigrants' LaborMarket Activity: An Evaluation of Alternative Explanations” American Economic Review, Vol. 87, No. 4, pp. 705-727.

Barrett, Garry F., (2002). “The Effect of Alcohol Consumption on Earnings”, Economic Record, Vol. 78, No. 240, pp. 79-98.

Beach, Charles M. and Worswick, Christopher, (1993). "Is There a Double-Negative Effect on the Earnings of Immigrant Women”, Canadian Public Policy, Vol. 19, pp.36-53.

Birch, Elisa Rose, (2006). “The Public-Private Sector Earnings Gap in Australia: A Quantile Regression Approach”, Australian Journal of Labour Economics, Vol. 9, No. 2, pp. 99128.

Blau, Francine D., Kahn, Lawrence M. and Portela-Souza, Andre, (2003). "The Role of Family in Immigrants' Labor Market Activity: An Evaluation of Alternative Explanations: Comment” American Economic Review, Vol. 93, No. 1, pp. 429-447.

Blau, Francine D., Kahn, Lawrence M., and Papps, Kerry L., (2011). “Gender, Source Country Characteristics, and Labor Market Assimilation Among Immigrants”, The Review of Economics and Statistics, Vol. 93, No. 1, pp. 43-58.

Chiswick, Barry R., (1978). "The Effect of Americanization on the Earnings of Foreign Born Men”, Journal of Political Economy, Vol. 86, No. 55, pp. 897-922.

Chiswick, Barry R., (1982). The Employment of Immigrants in the United States, Washington D.C.: American Enterprise Institute.

Chiswick, Barry R. and Miller, Paul W., (1985). "Immigrant Generation and Income in Australia”, Economic Record, Vol. 61, No. 173, pp. 540-553.

Chiswick, Barry R. and Miller, Paul W., (2006). “Immigration to Australia During the 1990s: Institutional and Labour Market Influences”, in Deborah A. Cobb-Clark and Siew-Ean Khoo (eds.) Public Policy and Immigrant Settlement, Edward Elgar Publishing, pp.3-24. 
Chiswick, Barry R. and Miller, Paul W., (2011). “The 'Negative’ Assimilation of Immigrants: A Special Case”, Industrial and Labor Relations Review, Vol. 64, No. 3, pp. 502-525.

Chiswick, Barry R. and Miller, Paul W., (2012). "Negative and Positive Assimilation, Skill Transferability, and Linguistic Distance”, Journal of Human Capital, Vol. 6, No. 1, pp.35-55.

Cobb-Clark, Deborah A., (1993). “Immigrant Selectivity and Wages: The Evidence for Women”, American Economic Review, Vol. 83, No. 4, pp.986-993.

Cobb-Clark, Deborah and Crossley, Thomas F., (2004). "Revisiting the Family Investment Hypothesis”, Labour Economics, Vol. 11, No. 3, pp.373-393.

Ferrer, Ana M. and Riddell, W. Craig, (2008). "Education, Credentials, and Immigrant Earnings”, Canadian Journal of Economics, Vol. 41, No. 1, pp. 186-216.

Lee, Yew Liang (2003). "Wage Effects of Drinking in Australia", The Australian Economic Review, Vol. 36, No. 3, pp. 265-82.

Miller, Paul W., (2005). “The Role of Gender Among Low-Paid and High-Paid Workers”, Australian Economic Review, Vol. 38, No. 4, pp. 405-417.

Miller, Paul W. and Neo, Leanne, (2003). "Labour Market Flexibility and Immigrant Adjustment”, Economic Record, Vol. 79, No. 246, pp. 336-356.

Pedersen, Peder J., Roed, Marianne and Wadensjo, Eskil, (2008). The Common Nordic Labour Market at 50, Copenhagen: Nordic Council of Ministers. 


\section{APPENDIX A \\ DEFINITIONS OF VARIABLES}

The variables used in the statistical analysis of the 2006 Australian Census of Population and Housing are defined below. The main set of analyses is restricted to foreign-born workers aged 20-64 years. Additional restrictions to the sample are discussed in the text.

\section{Dependent Variables \\ Log of Weekly Earnings Natural logarithm of weekly earnings (where earnings are defined as gross earnings from all sources). As weekly earnings were coded in intervals, midpoints of intervals were used to construct a continuous measure. The open-ended upper category was assigned a value of 1.5 times the lower threshold level. \\ Log of Hours Worked Natural logarithm of hours worked. Hours worked were recorded in individual hours up to 59, followed by an open- ended upper category of 60 or more. A value of 70 was assigned to this final upper interval. \\ Log of Hourly Earnings Natural logarithm of hourly earnings, defined as weekly earnings divided by hours worked. \\ Employment Indicator A dichotomous variable, set equal to one where the individual was employed at the time of the census, and set equal to zero for the unemployed and for those who were not in the labour force. \\ Unemployment A dichotomous variable relevant only for labor force Indicator participants, defined to equal 1 where the individual's labor force status was recorded as unemployed, and set equal to zero for individuals who were employed.}

\section{Explanatory Variables}

Years of Education

This is a continuous variable that records the equivalent years of full-time education completed by the individual. Individuals holding a Postgraduate degree are assigned 19 years of education, Graduate Diploma and Graduate Certificate holders are assumed to have 17 years, Bachelor degree holders have the equivalent of 15.5 years of education, advanced Diploma and Diploma holders are coded as having 14 years, holders of Certificates are assigned 13 years, those who have completed either Year 9 or any years through to Year 12 are coded as 9, 10, 11 and 12 years of education, respectively, and those who did not go to school or attained Year 8 or below are assumed to have 7 years of education. 
Experience

Marital Status

English Proficiency

Government

Employment

Birthplace of individual

Duration of Residence in Australia
The experience variable was derived using the Mincer (1974) proxy; Age - Years of Education - 5.

Dichotomous variable set to one if an individual is married at the time of the census and set to zero otherwise. Social marital status is used in this definition, so marriage refers to both registered and de facto marriages.

Five English skills categories are distinguished in the data set: (i) speaks only English at home; speaks a language other than English at home and speaks English (ii) very well; (iii) well; (iv) not well; (v) not at all. Dichotomous variables are included in the estimating equation that group those in the 'very well' and 'well' categories, and those in the 'not well' and 'not at all' categories, with the 'speaks only English at home' group being the benchmark group.

This is a dichotomous variable that distinguishes between those working in government organizations and those working in the private sector.

Individuals who were born overseas in the main Englishspeaking developed countries (ESDC) are distinguished from those born abroad in other countries (non-ESDC). The English-speaking developed countries of birth identified in the Australian census microdata file are New Zealand, England, Scotland, other United Kingdom and Ireland, the United States, and South Africa

This records the number of years an individual born overseas has lived in Australia. Both dummy variables based on the 11 year-of-arrival categories identified in the data (see text), and a continuous duration of residence variables constructed using the mid-points of the arrival periods are used in the estimations. 
Table A1

Descriptive Statistics of Variables by Gender and Birthplace Groups

\begin{tabular}{|c|c|c|}
\hline Variable & $\begin{array}{c}\text { Non-English-speaking } \\
\text { Countries }\end{array}$ & $\begin{array}{c}\text { English-speaking } \\
\text { Developed Countries }\end{array}$ \\
\hline \multicolumn{3}{|l|}{ Males: } \\
\hline Log Hourly Income & $\begin{array}{c}3.045 \\
(0.646)\end{array}$ & $\begin{array}{c}3.285 \\
(0.632)\end{array}$ \\
\hline Log Hours Worked & $\begin{array}{c}3.601 \\
(0.465)\end{array}$ & $\begin{array}{c}3.718 \\
(0.416)\end{array}$ \\
\hline Employment Rate & 0.738 & 0.858 \\
\hline Unemployment Rate & 0.072 & 0.033 \\
\hline Years of Education & $\begin{array}{l}13.540 \\
(3.250)\end{array}$ & $\begin{array}{l}13.084 \\
(2.535)\end{array}$ \\
\hline Years of Experience & $\begin{array}{c}24.715 \\
(12.206)\end{array}$ & $\begin{array}{c}27.550 \\
(11.307)\end{array}$ \\
\hline Duration of Residence & $\begin{array}{c}15.447 \\
(10.880)\end{array}$ & $\begin{array}{c}16.609 \\
(11.841)\end{array}$ \\
\hline Marital Status & 0.778 & 0.806 \\
\hline Government Sector & 0.092 & 0.109 \\
\hline English Only & 0.148 & 0.960 \\
\hline English Very Well/Well & 0.753 & 0.039 \\
\hline English Not Well/Not at All & 0.099 & 0.001 \\
\hline \multicolumn{3}{|l|}{ Females: } \\
\hline Log Hourly Income & $\begin{array}{l}2.977 \\
(0.649)\end{array}$ & $\begin{array}{c}3.134 \\
(0.636)\end{array}$ \\
\hline Log Hours Worked & $\begin{array}{c}3.375 \\
(0.603)\end{array}$ & $\begin{array}{l}3.389 \\
(0.595)\end{array}$ \\
\hline Employment Rate & 0.527 & 0.686 \\
\hline Unemployment Rate & 0.094 & 0.040 \\
\hline Years of Education & $\begin{array}{l}13.595 \\
(3.072)\end{array}$ & $\begin{array}{l}13.153 \\
(2.528)\end{array}$ \\
\hline Years of Experience & $\begin{array}{c}23.465 \\
(11.681)\end{array}$ & $\begin{array}{c}26.775 \\
(11.249)\end{array}$ \\
\hline Duration of Residence & $\begin{array}{l}14.687 \\
(9.992)\end{array}$ & $\begin{array}{c}16.863 \\
(11.547)\end{array}$ \\
\hline Marital Status & 0.735 & 0.749 \\
\hline Government Sector & 0.145 & 0.176 \\
\hline English Only & 0.182 & 0.959 \\
\hline English Very Well/Well & 0.723 & 0.041 \\
\hline English Not Well/Not at All & 0.095 & 0.0001 \\
\hline
\end{tabular}

Note: Standard errors in parentheses for continuous variables, and not reported for dichotomous variables. 